\title{
PERANCANGAN MESIN OTOMATIS PEMOTONG KERUPUK IKAN HARUAN
}

\author{
${ }^{(1)}$ Budi Hartadi, ${ }^{(2)}$ Firda Herlina, ${ }^{(3)}$ Ahmad Royani \\ (1)(2)(3)Program Studi Teknik Mesin, Universitas Islam Kalimantan MAAB \\ Jl. Adhyaksa No.2 Kayutangi banjarmasin \\ Email : akbar_mitrajaya@yahoo.com,tanyafirda@gmail.com
}

\begin{abstract}
Abstrak
Proses pemotongan kerupuk pada saat ini umumnya masih dilakukan secara manual yang hasilnya sedikit dan biayanya tinggi.selain secara manual pemotongan dengan menggunakan mesin mulai dikembangkan untuk mencapai hasil yang baik dan biaya produksi yang rendah. Masalah yang ingin di ketahui dalam penelitian ini adalah bagaimana merencanakan, melakukan pengujian dan pembandingan antara mesin potong dengan pemotongan secara manual.

Hasil penelitian menunjukkan bahwa Daya yang diperlukan motor untuk menggerakkan mesin adalah $0,25 \mathrm{hp}$, Sistem transmisi yang digunakan adalah menggunakan v-belt dengan panjang $1119,32 \mathrm{~mm}$ dari motor listrik ke Gearbox ukuran perbandingan 30:1 dengan jarak sumbu poros sebesar 200,5 mm dari Gearbox ke poros pisau pemotong, Perbandingan hasil potong mesin pemotong lontongan kerupuk ikan haruan dengan menggunakan tenaga manusia diperlukan biaya upah sebanyak Rp.5.000/jam dengan hasil pemotongan sebanyak $2 \mathrm{~kg} / \mathrm{jam}$ dan dengan menggunakan mesin pemotong lontongan ikan haruan dengan menggunakan 1 pisau adalah $15 \mathrm{~kg} / \mathrm{jam}$.
\end{abstract}

Kata kunci :Rancang bangun, Pemotong kerupuk, ikan haruan

\begin{abstract}
The process of cutting crackers at this time generally still done manually that the results are few and high cost. In addition to manually cutting by using the engine began to be developed to achieve good results and low production costs.

Problems that want to know in this research is how to plan, test and compare between cutting machine with cutting manually.

The results showed that the required power of the motor to drive the engine is $0.25 \mathrm{hp}$. The transmission system used is a v-belt with a length of 1119, $32 \mathrm{~mm}$ from an electric motor to a 30: 1 ratio gearbox and using a roll chain with a shaft length of 200,5 mm From Gearbox to cutting knife axle, Comparison of cutting machine cutting results of Haruan fish cracker by using human labor needed wage cost as much as Rp.5.000 / day with cutting result of $2 \mathrm{~kg} / \mathrm{hour}$ and by using fish cutting machine haruan by 1 knife is $15 \mathrm{~kg} /$ hour.
\end{abstract}

Keywords : Designer, Chopper Cutters, Haruan fish 


\section{PENDAHULUAN}

Perkembangan dan kemajuan ilmu pengetahuan dan teknologi terutama pada bidang teknologi dewasa ini semakin pesat. Sehingga dibutuhkan pemikiran untuk melakukan peningkatan kualitas dan kuantitas produk hingga diharapkan mampu menekan ongkos produksinya. Kemajuan teknologi ini juga tidak terlepas dari semakin beragam dan meningkatnya kebutuhan manusia. Beberapa penemuan dan penyempurnaan (modifikasi) sangat diperlukan untuk meningkatkan kerja mesin yang lebih efisien tanpa mengurangi kualitas dan peningkatan kuantitas produksi.

Bahan untuk membuat kerupuk biasanya terbuat dari bahan dasar tepung tapioka dicampur dengan bahan lain seperti udang atau ikan, garam penyedap rasa dan air sebagai bahan pencampur. Setelah bahan-bahan tersebut dicampur dan

diaduk hingga rata sehingga menjadi adonan kemudian dibungkus dengan daun pisang bentuk bulat panjang, setelah itu dikukus hingga masak selama lebih kurang 1 sampai dengan 2 jam. Adonan ditiriskan hingga kering atau kadar airnya berkurang kemudian diiris tipis-tipis setelah itu dikeringkan dengan menjemurnya di panas matahari. Selanjutnya adonan bisa digoreng menjadi kerupuk yang siap untuk dimakan.

Untuk perajangan adonan kerupuk di atas, masih banyak dilakukan secara manual dan ada pula yang menggunakan mesin pengiris / perajang. Tapi produk yang dihasilkan dengan cara manual masih berbentuk rajangan biasa dan relatif tidak sama. Sementara permintaan pasar menginginkan bentuk hasil produk relatif sama. Kemudian cara yang dilakukan dengan cara manual dinilai kurang efektif dan efisien bila melakukan produksi dalam jumlah besar.

Bila perajangan/pengirisan dilakukan dengan menggunakan mesin, hasil yang diperoleh relatif lebih baik dan produksi lebih tinggi serta waktu yang dibutuhkan lebih cepat. Maka dengan demikian dibutuhkan suatu mesin yang mampu merajang / mengiris kerupuk dengan waktu yang lebih cepat, lebih efisien tentunya juga lebih efektif, dengan kata lain perlu dirancang suatu mesin yang diharapkan mampu melakukan perajangan dengan hasil kerja yang lebih baik, bentuknya sederhana dan hasil perajangannya lebih berkualitas serta dapat memproduksi dalam jumlah lebih besar tetapi waktu yang digunakan juga lebih singkat.

\section{METODE PENELITIAN}

Tempat penelitian dilakukan di Bengkel Fakultas Teknik Jurusan teknik Mesin Universitas Islam Kalimantan (UNISKA) Banjarmasin Muhammad Arsyad Banjarmasin. Penelitian ini Banjary dilakukan selama kurun waktu delapan bulan, dari bulan Agt 2019-Februari 2020, dengan tahapan kegiatan sebagai berikut :

1. Mesin pemotong lontongan kerupuk tidak menggunakan tenaga penggerak manusia sebagai penggerak utamanya melainkan diganti dengan tenaga motor listrik.

2. Spesifikasi mesin yang ergonomis dengan dimensi yang nyaman bagi operator dan mudah disesuaikan dengan ruang kerja mesin berdimensi panjang $955 \mathrm{~mm} \times$ lebar $550 \mathrm{~mm} \times$ tinggi 600 $\mathrm{mm}$,menggunakan motor penggerak berkapasitas $1400 \mathrm{rpm}$, dan menggunakan gearbox dengan perbandingan $1: 30$.

3. Mudah dalam pengoperasian, perawatan maupun pergantian suku cadang mesin.

4. Pisau perajang dapat diatur untuk 
menentukan ketebalan hasil rajangan sesuai dengan yang diinginkan.

5. Mesin pemotong lontongan kerupuk ini tidak mengaplikasikan bahan yang berbahaya bagi keselamatan.

6. Mesin pemotong ini tidak menimbulkan pencemaran udara.

7. Pada saat beroperasi, mesin ini tidak menimbulkan suara yang bising.

\section{HASIL DAN PEMBAHASAN}

\section{Teknik Perancangan Mesin Pemotong Kerupuk}

Teknik perancangan adalah langkah dasar yang sangat penting dilakukan dalam perancangan mesin pemotong lontonganan kerupuk ini. Tujuan dari teknik perancangan ini adalah untuk mendapatkan data-data konstruksi yang dibutuhkan dalam membangun mesin pemotong lontonganan kerupuk.

Kapasitas produksi alat

Berdasarkan hasil pengukuran dilapangan didapatkan bahwa kapasitas produksi alat adalah $0,4 \mathrm{Kg}$ per menit atau $1 \mathrm{Kg}$ per 15 menit.

Pengujian alat pemotong dengan menggunakan motor penggerak 1250 rpm dengan ketebalan $1 \mathrm{~mm}$ dengan ratio gearbox 1: 30 didapatkan sebanyak 43 irisan dengan berat 4,5 gram dan berat hasil pemotongan selama 1 menit adalah 193,5 gram, kemudian dengan ketebalan $2 \mathrm{~mm}$ didapatkan sebanyak 39 irisan dengan berat 8,3 gram dan berat hasil pemotongan selama 1 menit adalah 323,7 gram, dengan ketebalan $3 \mathrm{~mm}$ didapatkan sebanyak 38 irisan dengan berat 8,3 gram dan berat hasil pemotongan selama 1 menit adalah 520,6 gram.

Pengujian alat pemotong dengan menggunakan motor penggerak 1500 rpm dengan ketebalan $1 \mathrm{~mm}$ dengan ratio gearbox 1: 30 didapatkan sebanyak 51 irisan dengan berat 4,1 gram dan berat hasil pemotongan selama 1 menit adalah 209,1 gram, kemudian dengan ketebalan
$2 \mathrm{~mm}$ didapatkan sebanyak 48 irisan dengan berat 7,8 gram dan berat hasil pemotongan selama 1 menit adalah 374,4 gram dan dengan ketebalan $3 \mathrm{~mm}$ didapatkan sebanyak 46 irisan dengan berat 13,2 gram dan berat hasil pemotongan selama 1 menit adalah 607,2 gram.

Dari hasil pengujian mesin pemotong maka dapat disimpulkan bahwa semakin tebal hasil pemotongan maka jumlah irisan semakin sedikit walaupun berat total hasil pemotongan semakin meningkat.

\section{KESIMPULAN}

1. Daya yang diperlukan motor untuk menggerakkan mesin adalah $0,1 \mathrm{hp}$ namun motor listrik daya terkecil yang tersedia dipasaran adalah 0,25 hp sehingga mesin pemotong lontongan kerupuk ikan haruan menggunakan motor daya $0,25 \mathrm{hp}$.

2. Sistem transmisi yang digunakan adalah menggunakan v-belt dengan panjang 1119 ,32 mm dari motor listrik ke Gearbox ukuran perbandingan 30:1 dan menggunakan rantai roll Nomor 50 dengan jumlah 46 mata rantai, jarak sumbu poros 200,5 mm dan jumlah Gigi Sprocket 15 dan 26.

3. Perbandingan kapasitas hasil potong mesin pemotong lontongan kerupuk ikan haruan dengan menggunakan tenaga manusia diperlukan biaya upah sebanyak Rp.5.000/jam dengan hasil pemotongan sebanyak $2 \mathrm{~kg} / \mathrm{jam}$ dan dengan menggunakan mesin pemotong lontongan kerupuk ikan haruan dengan menggunakan 1 pisau adalah $15 \mathrm{~kg} / \mathrm{jam}$, sedangkan biaya listrik per Kwh nya adalah Rp 1352 untuk listrik bersubsidi dan Rp 1467,28 untuk non subsidi, Dengan motor yang digunakan adalah 0,25 hp maka perhitungan ekonomisnya adalah $0,25 \times 746=186$ watt atau $0,186 \mathrm{Kwh}$, diambil harga listrik non 
subsidi untuk pelaku ukm yaitu Rp 1467,28 , maka $1467,28 \times 0,186=\mathrm{Rp}$ 272,91/jam.

\section{REFERENSI}

[1] Eriana Rusitawati, 2015. Rancang Bangun prototype alat pemotong kerupuk Mikrokontroller AT89S51. Universitas Diponegoro. Semarang

[2] Hastomo , Tri,2013 Perancangan dan pembuatan alat pemotong krupuk rambak dengan pendekatan Quality Function Deployment (QFD) ( Studi Kasus : Sentra Industri Krupuk Rambak, Desa Doplang, Teras, Boyolali ). Universitas Muhammadiyah Surakarta.Surakarta

[3] Haryadi sinuart, Dkk, 2015. Rancang Bangun Mesin Perajang adonan kerupuk Kapasitas 100Kg/Jam. Politeknik Negeri Medan. Medan

[4] lham ahmad Siregar, Dkk, 2014. Rancang bangun Mesin pemotong Adonan Kerupuk Udang Kapasitas 60Kg/Jam. Politeknik Negeri Medan.Medan

[5] Muhammad Khairul Anam, 2015. Perancangan Mesin pemotong Adonan kerupuk $84 \mathrm{Kg} / \mathrm{Jam}$. Universitas Muhamadiyah. Ponorogo.

[6] Nieman,1999. Elemen Mesin jilid I,disain dan kalkulasi dari sambungan, bantalan dan poros.Erlangga.Jakarta.

[7] Smith, H. P., dan L. H. Wilkes. 1990. Mesin dan Perlatan Usaha Tani. Gadjah Mada University Press. Bulaksumur. Yogyakarta 